\title{
EVALUASI FASILITAS RUANG TUNGGU UNTUK PENINGKATAN KUALITAS PELAYANAN DENGAN PENDEKATAN MIKRO DAN MAKRO ERGONOMI DI STASIUN KERETA API MALANG
}

\author{
Mardiki Supriadi \\ ${ }^{1}$ Program Studi Teknik Industri, Fakultas Teknik, Universitas Mahendradatta \\ JI. Ken Arok No.12, Peguyangan, Denpasar, Bali 80115 \\ Email: mardiki@yahoo.co.id
}

\begin{abstract}
Abstrak- Stasiun kereta api di Malang merupakan salah satu stasiunyangberada dibawah pengawasan PT. Kereta Api Indonesia (Persero), yang bergerak dalam bidang usaha penyediaan jasa transportasi darat. Banyaknya jumlah penyedia jasa transportasi mendorong persaingan antara penyedia jasa transportasi untuk memberikan pelayanan yang baik guna memuaskan keinginan konsumen. Kualitas pelayanan dan kondisi fasilitas yang ada pada stasiun kereta api di Malang khususnya bagian ruang tunggu masih belum memenuhi Standar Pelayanan Minimum untuk Angkutan Orang dengan Kereta Api berdasarkan Peraturan Menteri Perhubungan No. PM 9 tanggal 8 Febuari 2011. Oleh sebab itu perlu adanya identifikasi dan penilaian kondisi fasilitas ruang tunggu serta analisis dan evaluasi yang dilakukan untuk peningkatan kualitas pelayanan dengan pendekatan Mikro dan makro ergonomi. Dengan pendekatan Mikro Ergonomi akan diberikan usulan perbaikan untuk mengatasi masalah lingkungan kerja (temperatur udara dan tingkat intensitas bunyi) di bagian ruang tunggu Stasiun kereta api. Dengan pendekatan Makro Ergonomi akan dilakukan perancangan ulang sistem kerja pada bagian ruang tunggu Stasiun kereta api yang dapat diimplementasikan oleh pihak pengelola Stasiun kereta api. Penelitian ini bertujuan untuk mengidentifikasi, menganalisis permasalahan dan memberikan usulan perbaikan pada kondisi fasilitas dibagian ruang tunggu dengan pendekatan Mikro dan makro ergonomi guna peningkatan kualitas pelayanan pada Stasiun Kereta Api di Malang. Penelitian ini memaparkan kondisi fasilitas yang ada pada bagian ruang tunggu Stasiun Kereta Api di Malang melalui kuisioner yang disebarkan kepada pengguna jasa kereta api. Dengan mengetahui kondisi tersebut, dilakukan pengukuran kondisi lingkungan kerja pada bagian ruang tunggu Stasiun Kereta api. Diperoleh hasil pengukuran temperatur udara di bagian ruang tunggu berkisar pada 31-35,3oC dan tingkat intensitas bunyi pada bagian ruang tunggu berkisar pada 66,8-88,1dB. Kemudian dilakukan pemecahan masalah dengan pendekatan Makro Ergonomi menggunakan metode MEAD (Macro Ergonomic Analysis and Design) melalui sepuluh tahapan proses dan diperoleh hasil pemilihan alternatif yaitu melakukan perbaikan serta pengadaan fasilitas di bagian ruang tunggu, pelatihan petugas pada Stasiun kereta api dan perbaikan budaya atau kebiasaan penumpang. Dari penelitian ini diberikan usulan perbaikan fasilitas ruang tunggu pada Stasiun kereta api di Malang yang dapat diimplementasikan oleh pihak manajemen PT. Kereta Api Indonesia (Persero) guna peningkatan kualitas pelayanan Stasiun kereta api.
\end{abstract}

Kata Kunci: Mikro Ergonomi, MEAD (Macro Ergonomic Analysis and Design), dan Evaluasi Fasilitas Ruang Tunggu.

Abstract- The train station in Malang is one of the stations under the supervision of PT. Kereta Api Indonesia (Persero), which is engaged in the business of providing land transportation services. The large number of transportation service providers encourage competition between transportation service providers to provide good service to satisfy consumer desires. Service quality and condition of facilities available at railway stations in Malang, especially the waiting room section, still do not meet the Minimum Service Standards for People Transportation by Train based on the Minister of Transportation Regulation No. PM 9 on February 8, 2011. Therefore it is necessary to identify and evaluate the condition of waiting room facilities and the analysis and evaluation carried out to improve service quality with a Micro and macro ergonomics approach. With the Micro Ergonomics approach 
there will be proposed improvements to overcome work environment problems (air temperature and sound intensity level) in the train station waiting room. With the Ergonomics Macro approach a work system will be redesigned in the train station waiting room section that can be implemented by the train station manager. This study aims to identify, analyze problems and propose improvements to the condition of facilities in the waiting room section with a Micro and macro ergonomics approach to improve service quality at the Railway Station in Malang. This study describes the condition of facilities in the Railway Station waiting room in Malang through a questionnaire distributed to train service users. By knowing these conditions, a measurement of the working environment conditions is carried out on the train station waiting room. Obtained results of air temperature measurements in the waiting room area ranged from $31-35.30 \mathrm{C}$ and the level of sound intensity in the waiting room section ranged from 66.8 to $88.1 \mathrm{~dB}$. Then the problem solving using the Macro Ergonomics approach using the MEAD method (Macro Ergonomic Analysis and Design) through ten stages of the process and obtained alternative selection results, namely repairs and procurement of facilities in the waiting room, officer training at the railway station and improvement of culture or passenger habits. From this study, a proposal to improve the waiting room facilities at the railway station in Malang was proposed which could be implemented by the management of PT. Kereta Api Indonesia (Persero) to improve the service quality of the train station.

Keywords : Micro Ergonomics, MEAD (Macro Ergonomic Analysis and Design), and Facility Evaluation of Waiting Room.

\section{PENDAHULUAN}

Jasa transportasi yang ada meliputi jalur darat seperti bus dan kereta api, jalur laut seperti kapal, dan jalur udara seperti pesawat udara. Banyaknya jumlah penyedia jasa transportasi mendorong persaingan antara penyedia jasa transportasi untuk memberikan pelayanan yang baik guna memuaskan keinginan konsumen. Di daerah Jawa Timur khususnya, bus menjadi sarana transportasi darat yang sangat diminati dibandingkan kereta api. Kualitas pelayanan pada kereta api dan kondisi fasilitas fisik yang ada masih belum memenuhi standar pelayanan minimum ini menjadi salah satu faktor penyebab berkurangnya peminat pengguna jasa kereta api.

Oleh sebab itu perlu dilakukan kajian untuk memperbaiki kondisi fasilitas fisik yang ada pada stasiun kereta api. Perbaikan ini memerlukan peninjauan dan penilaian pada skala mikro ergonomi. Namun seiring dengan perkembangan keilmuan saat ini, penilaian ini tidak bisa hanya dari sisi mikro ergonomi, tetapi perlunya pendekatan dari sisi makro ergonomi untuk bisa mengimplementasikan perbaikan yang ada pada lingkungan organisasi. Makro ergonomi merupakan suatu pendekatan sosioteknik dari tingkat atas kebawah yang diterapkan pada perancangan sistem kerja secara keseluruhan dengan tujuan mengoptimalkan desain sistem kerja dan memastikan sistem kerja tersebut berjalan dengan harmonis menurut Hendrick \& Kleiner (2002).

Dengan pendekatan makro ergonomi, akan dilakukan perancangan sistem kerja pada stasiun kereta api secara keseluruhan dan usulan perbaikan kondisi fasilitas ruang tunggu pada khususnya yang dapat diimplementasi oleh pihak pengelola kereta api sehingga dapat meningkatkan kualitas pelayanan dan kepuasan pengguna jasa kereta api. Dengan adanya peningkatan kualitas pelayanan kereta api di Malang, diharapkan dapat meningkatkan jumlah pengguna kereta api sehingga kereta api bisa menguasai dan menjadi leader untuk jasa transportasi darat di wilayah Jawa Timur.

\section{METODE PENELITIAN}

Jenis penelitian ini termasuk dalam penelitian deskriptif karena penelitian ini bertujuan untuk mendeskripsikan permasalahan yang ada pada fasilitas ruang tunggu stasiun kereta api dan memberikan usulan perbaikan fasilitas ruang tunggu stasiun kereta api di Malang tanpa diimplementasikan. Berdasarkan analisis dan jenis data, penelitian ini termasuk dalam penelitian gabungan karena penelitian ini menggunakan data yang bersifat kuantitatif dan kualitiatif.

Objek yang diteliti pada penelitian ini adalah menganalisis fasilitas ruang tunggu 
stasiun kereta api di Malang dan memberikan evaluasi untuk meningkatkan kualitas pelayanan dengan pendekatan mikro dan makro ergonomi. Penelitian ini dilakukan pada Stasiun Kereta Api yang berlokasi di Malang, Jawa Timur. Adapun lokasi penelitian khusus pada bagian ruang tunggu stasiun kereta api. Waktu pelaksanaan pengambilan data penelitian yaitu selama 1 bulan dimulai pada tanggal 1 s/d 30 September 2018. Adapun beberapa jenis data yang dikumpulkan dalam melakukan penelitian ini adalah data primer dan data sekunder.

\section{HASIL DAN PEMBAHASAN}

Pada penelitian ini dilakukan penyebaran kuisioner terbuka kepada 30 orang penumpang yang ada di Stasiun Malang untuk mengetahui persepsi penumpang kereta api mengenai: kondisi fasilitas, pelayanan yang diberikan pihak pengelola kereta api, lingkungan kerja stasiun kereta api, dan kemudahan akses informasi yang disediakan pihak pengelola kereta api.

Tabel 3.1 Analisis pada Tahapan MEAD

\section{No: Tahapan MEAD}

\begin{tabular}{|c|c|c|}
\hline 1 & Pemeriksaan lingkungan organisasi & \multirow{3}{*}{$\begin{array}{l}\text { Pembuatan diagram } \\
\text { pohon permasalahan }\end{array}$} \\
\hline 2 & Pendefinisian sistem operasi & \\
\hline 3 & Pendefenisian unit operasi dan proses kerja & \\
\hline 4 & Identifikasi varians & \\
\hline 5 & Pembuatan matriks varians & \\
\hline 6 & Pembuatan tabel kontrol & \\
\hline 7 & $\begin{array}{l}\text { Pembuatan alokasi fungsi dan pembobotan } \\
\text { alternatif }\end{array}$ & \\
\hline 8 & $\begin{array}{l}\text { Penjelasan aturan dan persepsi tanggung jawab } \\
\text { (Analisa peran dan tanggung jawab) }\end{array}$ & \\
\hline 9 & Perancangan ulang sub sistem & \\
\hline 10 & Iterasi, implementasi dan improvisasi & \\
\hline No: & Tahapan MEAD & \multirow{4}{*}{$\begin{array}{l}\text { Pembuatan diagram } \\
\text { pohon permasalahan }\end{array}$} \\
\hline 1 & Pemeriksaan lingkungan organisasi & \\
\hline 2 & Pendefinisian sistem operasi & \\
\hline 3 & Pendefenisian unit operasi dan proses kerja & \\
\hline 4 & Identifikasi varians & \\
\hline 5 & Pembuatan matriks varians & \\
\hline 6 & Pembuatan tabel kontrol & \\
\hline 7 & $\begin{array}{l}\text { Pembuatan alokasi fungsi dan pembobotan } \\
\text { alternatif }\end{array}$ & \\
\hline 8 & $\begin{array}{l}\text { Penjelasan aturan dan persepsi tanggung jawab } \\
\text { (Analisa peran dan tanggung jawab) }\end{array}$ & \\
\hline 9 & Perancangan ulang sub sistem & \\
\hline 10 & Iterasi, implementasi dan improvisasi & \\
\hline
\end{tabular}


Kuesioner terbuka yang digunakan memuat 10 pertanyaan yang meliputi: frekuensi penggunaan jasa kereta api, fasilitas yang diinginkan, kondisi fasilitas toilet, kondisi fasilitas kursi, pelayanan pihak pengelola kereta api, kondisi temperatur ruang tunggu stasiun kereta api, akses informasi tentang jadwal keberangkatan, akses informasi mengenai rute dan tarif tiket, keramahan pihak pengelola kereta api, keunggulan jasa kereta api. Pada kuesioner terbuka ini, responden bebas mengisi kuesioner sesuai dengan keinginannya masing-masing.

Setelah dilakukan analisis pemecahan masalah dengan pendekatan Mikro Ergonomi kemudian dilakukan analisis pemecahan masalah dengan pendekatan Makro Ergonomi melalui metode MEAD (Macro Ergonomic Analysis and Design). Analisis pemecahan masalah dilakukan pada sepuluh tahapan MEAD yang dapat dilihat pada Tabel 3.1.

Analisis tahapan pada sepuluh tahapan MEAD yaitu tahapan pemeriksaan lingkungan organisasi, pendefinisian sistem dan pendefinisian unit operasi yang dirangkum dalam pembuatan diagram pohon permasalahan. Pembuatan diagram pohon permasalahan dapat dilakukan setelah terlebih dahulu melakukan peninjauan terhadap sistem yang ada. Pada tahapan pemeriksaan lingkungan organisasi didapatkan permasalahan-permasalahan yang terjadi pada bagian ruang tunggu Stasiun kereta api yang terangkum dalam diagram pohon permasalahan. Selanjutnya dilakukan identifikasi varians, pembuatan matriks varians dan tabel kontrol. Analisis terhadap tahapan pembuatan alokasi fungsi dan pembobotan alternatif, analisa peran, perancangan ulang sub sistem dan implementasi pada lingkungan organisasi yang dapat dilakukan, meliputi:

1. Penambahan jumlah petugas pada stasiun kereta api

Penambahan petugas yang bertugas di Stasiun kereta api meliputi: penambahan satu orang petugas Supervisor pelayanan stasiun yang bertugas untuk melakukan pergantian display informasi dan dua orang petugas customer service untuk melayani dan memberikan informasi kepada penumpang. Usulan perbaikan yang diberikan membutuhkan analisis sistem kerja untuk menentukan petugas yang melakukan perbaikan yang sesuai dengan tugas dan tanggung jawab.

\section{Perbaikan dengan pengadaan fasilitas}

Pengadaan fasilitas dibagian ruang tunggu meliputi: peralatan kebersihan toilet, alat pendingin ruangan, loudspeaker, display informasi mengenai harga tiket dan peta rute perjalanan kereta api, serta display informasi mengenai nomor dan jenis kereta api, jalur dan lokasi peron kereta api tujuan. Usulan perbaikan yang diberikan membutuhkan analisis sistem kerja untuk menentukan petugas yang melakukan perbaikan yang sesuai dengan tugas dan tanggung jawab.

3. Sosialisasi display informasi yang ada kepada penumpang kereta api

Sosialisasi mengenai display informasi akan diberikan oleh pihak petugas customer service sehingga penumpang dapat mengerti mengenai informasi yang diberikan. Usulan perbaikan yang diberikan membutuhkan analisis sistem kerja untuk menentukan petugas yang melakukan perbaikan yang sesuai dengan tugas dan tanggung jawab.

4. Memberikan pengarahan dan pengontrolan tugas petugas kereta api

Pengontrolan tugas petugas cleaning service akan dilakukan secara berkala sehingga toilet pada bagian ruang tunggu Stasiun kereta api bersih dan terawat. Pengarahan akan diberikan kepada petugas customer service agar bisa menyampaikan informasi dan memberikan pelayanan yang baik kepada penumpang. Usulan perbaikan yang diberikan membutuhkan analisis sistem kerja untuk menentukan petugas yang melakukan perbaikan yang sesuai dengan tugas dan tanggung jawab. Penugasan pengadaan dan pemasangan fasilitas serta pemberian layanan informasi dilakukan oleh Asisten Manager Customer Care dan Asisten Manager Pelayanan dengan bantuan petugas untuk melakukan pemasangan fasilitas dan sosialisasi kepada penumpang mengenai 
fasilitas. Asisten manager customer care bertugas untuk melakukan pengawasan pada proses pelayanan yang diberikan petugas customer service. Asisten Manager Pelayanan bertugas untuk mengawasi proses pergantian display informasi dan pengadaan fasilitas.

Kepala stasiun memiliki wewenang untuk melakukan koordinasi dan mengawasi sepenuhnya kegiatan pengadaan dan pemasangan fasilitas serta pelayanan informasi dapat berjalan lancar. Manager komersial memiliki wewenang terhadap kelancaran proses angkutan penumpang. Manager Komersial bekerja sama dengan Manager Operasional, Manager Sarana dan Manager Keuangan di dalam melakukan pengadaan fasilitas. Manager sarana bertanggung jawab atas proses pengadaan dan perawatan fasilitas agar sesuai dengan kebutuhan di bagian ruang tunggu stasiun kereta api. Manager keuangan bertugas untuk mengeluarkan biaya yang diperlukan untuk membeli fasilitas sesuai dengan perencanaan kebutuhan yang dibuat Manager Sarana. Manager Komersial juga bekerja sama dengan Manager SDM dan Manager Keuangan dalam melakukan penambahan jumlah petugas di Stasiun kereta api.

Manager Komersial, Manager Operasional, Manager Sarana, Manager Keuangan dan Manager SDM bertanggung jawab secara langsung kepada Deputy VP atas terlaksananya proses pengadaan dan pemasangan fasilitas serta penambahan jumlah petugas di Stasiun kereta api. Deputy VP bertanggung jawab secara langsung kepada VP Divre I Jawa Timur. VP Divre I Jawa Timur bertugas untuk mengkoordinasikan seluruh unit kerja dari bagian operasional dan memberikan pengawasan agar tercapainya tujuan perusahaan. VP regional bertanggung jawab kepada seluruh jajaran direksi dan direktur utama.
Pelayanan Minimum untuk Angkutan Orang dengan Kereta Api mengacu pada Peraturan Menteri Perhubungan No.9 Tanggal 8 Febuari 2011.

2. Temperatur udara pada bagian ruang tunggu stasiun kereta api selama satu minggu pengamatan berada pada rentang $31-35,30 \mathrm{C}$ sehingga penumpang merasa kepanasan dan gerah ketika menunggu kedatangan kereta api tujuan.

3. Tingkat intensitas bunyi pada bagian ruang tunggu Stasiun Kereta api berada pada rentang 66,8 dB sampai $88,1 \mathrm{~dB}$. Tingkat intensitas bunyi yang cukup tinggi di bagian ruang tunggu ini, sangat mengganggu jalannya informasi yang diberikan oleh pihak Petugas Perjalanan Kereta Api (PPKA) dengan mic melalui loud speaker yang ada.

4. Tingkat pencahayaan pada bagian ruang tunggu stasiun kereta api berada pada rentang 200-215 lux. Tingkat pencahayaan yang ada sudah memenuhi standar pencahayaan yang direkomendasi untuk pekerjaan kasar dengan detail besar pada aktivitas yang biasa dilakukan penumpang di bagian ruang tunggu seperti: membaca koran yaitu 200 lux.

\section{DAFTAR PUSTAKA}

Hendrick, Kleiner. 2002. Macroergonomics Theory, Methods and Aplication. Lawrence Erlbaum Inc: New Jersey

Manual For Standarization and Specification for Railway Station in India. 2009. Ministry of Railway Government of India.

Peraturan Menteri Perhubungan Nomor 9 Tahun 2011 tentang Standar Pelayanan Minimum untuk Angkutan Orang dengan Kereta Api

Roscoe. 1975. Fundamental Reasearch Statistic for the Behavioural. Second Edition:New York

Saputra, Andrias. 2010. Cara Menghitung Jumlah Kebutuhan AC. (Andrias-

\section{KESIMPULAN}

1. Kondisi fasilitas pada bagian ruang tunggu Stasiun kereta api di Malang masih belum sesuai dengan Standar 